UDC 116:378.046 -021.68

DOI: https://doi.org/10.30839/2072-7941.2019.165106

\title{
THE MODERN PARADIGM OF NON-ACADEMIC EDUCATION IN THE CONTEXT OF UNLIMITED PROFESSIONAL EDUCATION
}

\author{
(C) OLGA, KYVLIUK \\ National Pedagogical Dragomanov University (Kyiv, Ukraine) \\ E-mail: panyolga@ukr.net, ORCID: 0000-0002-7900-9299 \\ (C) GALINA, ZHUKOVA \\ National Pedagogical Dragomanov University (Kyiv, Ukraine) \\ E-mail: galinazh1299@gmail.com, ORCID: 0000-0002-1248-4669
}

\begin{abstract}
The relevance of the research. Consideration of continuous professional education as a social institution determines the relevance of the integration approach, which involves the use of a complex of measures for the integration and interdisciplinary of modern scientific knowledge, the search for new contexts of education as a productive direction for the development of scientific research, where non-academic education acts as an activity paradigm requiring theoretical analysis and scientific justification. The purpose of the paper is to analyze the peculiarities of non-academic education as a modern paradigm that allows the formation of a creative specialist to be able of professional and personal self-development, for the theoretical justification of changing the educational field. Analysis of recent research and publications. The concept of continuing education as a modern educational paradigm was considered in works: V. Byashenko [1], V. Voronkova [3], T. Desiatova [4], O. Kyvliuk [8], L. Lukyanova [9], V. Orlov [10] and others. Research methodology. The systematic, informational, synergetic methods and approaches are used for analyzing the modern paradigm of non-academic education in the scientific research. Presenting main material. The making of non-academic education is considered as a socio-cultural phenomenon, which reflects the growing need of an individual in obtaining various educational services. This educational system has such features as: organization, system, professional orientation, continuity, topicality in existing knowledge acquired by a person outside the academic educational system. The main principles of non-academic education according to the research of native and foreign scientists and Ukrainian state programs are: orientation of training to meet the actual needs of its subjects; communication with practice, which manifests itself in the pursuit of life skills and preparation for active participation in society; availability of mobile flexible programs, individual educational strategies aimed at expressing, accepting and respecting individual peculiarities. Conclusions. The modern paradigm of non-academic education acts as an activity form of the development of a personality and a specialist, based on the principles of creating a productive and not reproductive system of transmitting and receiving knowledge, taking into account the whole variety of subjective and objective challenges of our time.
\end{abstract}

Key words: continuous education, professional education, non-academic education, system of the education, information society.

The relevance of the research. Due to the sweeping changes taking place in the society en bloc and in the system of education in particular, vocational education guidelines are changing. To the number of the important and large-scale systems the development of which requires scientific analysis and practical solutions that satisfy the current (C) Olga Kyvliuk \& Galina Zhukova, 2019 
conditions, take the non-academic education as such education, which is not obtained in academic institutions of education. In modern conditions, the system of non-academic education can become the main link between the professional and educational interests of the individual, society and the state and between different levels of vocational education and branches of the socio-economic sphere, employers' requirements and the requests of direct consumers of educational services.

The functioning and development of the education system as a sociophilosophical institution is characterized by specific internal contradictions, which are reflected in the scientific knowledge of many theoretical problems. Philosophical run-in can be separated with the totality of problems along with the pedagogical and psychological ones; they reflect the contradictory interactions of the education system with society as a global social system. The relationship and interaction of the education system with the interrelation of society, expressed in its structure, constitute the leading direction of philosophical problems of education.

Analysis of recent research and publications. A wide range of problems forming the educational system due to its multidimensional nature is based on various theoretical approaches. In particular, the aspects of this problem are found in the works of V. Volkovsky [2], who considered the idea of a society in Ukraine, noting the importance of non- academic studies on which he relied. Valuable for our study is that he conducted a philosophical line from the journalistic activities of the early nineteenth century to modern Internet projects. In the philosophical system of non-academic education, scholars V. Dolgotchub and N. Petrov [5] found that non-academic activities have nothing to do with academic or professional academic education. In their view, every vital or educational fact needs to be considered in accordance with its heterogeneity, regardless of whether the boundaries between their structural components are brightly or weakly expressed [5]. Considering the nature of nonacademic science, Z. Zaitseva [6] sees it as "the localization of the Ukrainian scientific space, which is inherent in a historical two-centralization " $[6, \mathrm{p}$. 29]. Even at the beginning of the 20th century institutions of higher education of Ukraine aspired autonomy in order to dominate the ideal of pure science, which could create a unification of the intellectual world with political [6, p. 29]. The world-famous education expert, English scientist Ken Robinson [18] emphasizes the need for a revolutionary change in the paradigm of education from academic to nonacademic. The causes of rebuilding are economic and cultural changes in the society of the twenty-first century, which reveal the intellectual potential of society [18]. As a scientific category, the concept of "nonacademic education" is considered by the Polish scientist B. Kshish, which formulates the academic and non-

The modern paradigm of non-academic education in the context of unlimited professional education 
academic forms of education as the central interconnected worlds of science. He marks a need to raise the importance of non-academic science in society and the state as a mobile and relevant link in the educational system [17].

The purpose of the paper is to analyze the special aspects of nonacademic education as a modern paradigm that enables the formation of a creative specialist to be capable of professional and personal selfdevelopment in order to the theoretical substantiation of changing the educational field.

Presenting the main material. The problem of the "relationship" between education and a person has always been a subject of philosophers' reflection. The content of education should clearly indicate the compulsory discipline, hours, objectives, methods, tasks, competencies that meet the standards of a particular specialty. And the main results of education are the formation of the integrity of the individual, independence, subjectivity of a man in all manifestations of his activity, the unity of two cultures, mental activity and practice, professionalism, the ability to reflect on those or other parties and the results of his personal and collective life.

Classical academic education is largely based on a subject approach, when knowledge is acquired from individual disciplines that are a part of the program content of a chosen specialty. Unfortunately, the amount of this knowledge does not always guarantee the success of future professional activities. The modern professional environment requires interdisciplinary and integration, which to some extent helps to comprehend the structure of nonacademic education. In this regard, traditional education becomes inadequate, and a specialist with higher education is forced after obtaining a patent to acquire additional knowledge in numerous non-academic education courses. The final state attestation in classical academic education does not always contribute to solving the internationalist problem of a specialist, increasing his ability to mutually connect fragments of knowledge into a single whole and solve complex problems of the professional environment. One of the ways out of this situation is nonacademic education, which is based on the use and development of the creative potential of a person, manifested in flexible, associative thinking and allows connecting not only logically related fields of knowledge, but also creating new interconnections.

The

system-philosophical approach to education is characterized by the fact that education is considered as a self-sufficient phenomenon, having its own structure, scheme consisting of functions and subsystems. Inasmuch as education is a socio-cultural subsystem with its state, educational institutions can be identified as its main elements as social organizations, social communities, educational process as a type of activity. The most important characteristic of the Institute of Education is the 
organization of educational activities and relationships, which are carried out with the help of a mutually agreed system of expediently oriented standards of conduct, which testifies to the impersonal nature of education. The institutional form of education leaves out of its attention the development of a man as a subject of activity and his self-education as such an internal force that this person enters into action.

Non-academic education as well as additional vocational education, education in the context of professional development, selfeducation, postgraduate education are an integral part of continuing education. Native non-academic education acquires its characteristic features, which are largely formed by the theoretical constructions of the humanities. The beginning of the formation of non-academic education not so much characterized the epoch as comprehensive information, but more pointed to the development of education. Indeed any innovation has its own range of characteristics and qualities, its own historical context and cannot dominate at very long stages of development of society, but only directs progress towards the future [14].

Another powerful challenge of time in the information-globalizing society is the individualization and autonomization of the subject of nonacademic education. This autonomy, undoubtedly, acts as a protective response to globalization and universalization. But it is essential that this trend, immanent for modern society, gives a rise to another characteristic phenomenon alienation from socially significant results of educational activities. However, not all these factors, with all their significance, are decisive in reflecting the prospects for the development of continuous educational activities in the information society. Here the first place is the Internet phenomenon, which is associated with the ground of a new model of social world order in the information society. This is due to the fact that non-academic education is primarily focused on social processes and events. Particularly relevant are hybrid international educational institutions. Of course, one of their tasks is to determine the essence of this phenomenon, natural relationships, socio-cultural factors that determine its functioning and development. It is important to forecast trends, alternatives to development, scientific substantiation and design of normative and variable models of non-academic education in the world educational space.

The process of education and, as a result of it, accomplishment creates the very possibility of non-academic study so it not only develops the intellectual abilities of people, but also plays a crucial role in the subject's understanding of learning, responsibility for learning outcomes, developing its will, necessary motivating for a solid work on the development of scientific knowledge and their use in innovation activity, forming moral and ethical qualities. In this attitude it is important to keep in

The modern paradigm of non-academic education in the context of unlimited professional education 
mind that real professionalism cannot be taught; professional school lays only its foundations and upwards of professional intent of activity. Professionalism is always the inconclusive result of education and self-education, constant selfimprovement of a person in cognition and labor [4]. Teaching professionalism really can be only narrow, one-sided and primitive at the level of craftsmanship. This occurs for various reasons, including the result of the identification of education and training.

Paradigm transformations in education, the formation of postneoclassical type of it, cause a change in the strategies and technologies of scientific research. The non-academic education is characterized by openness and dynamism of samples, methodological norms and rationality, when its programs are in the focus of permanent critical reflection and, as a result, transformation. Non-academic education introduces the human dimension into activity, defining the basic principles of mutually complementary rational-logical and subjective-irrational self-valuable components, the variability of approaches to learning, the dialogue and complementarity of approaches, polyconception, relativity and multidimensionality [15]. Now, in the new realities, practicing teachers, teachers in post-academic education institutions, as subjects of knowledge, adherents of various methodological strategies always have the right to choose the methodological basis of their own subjectivism.
Academic and non-academic educations take an exchange of assets with the disclosure of the diversity of new contexts. The development of non-academic education is not very smooth because of people's reluctance to perceive new, unknown changes in their lives. We see the effectiveness of non-academic study in continuous professional self-development, which can be evaluated by monitoring the motivational-value, informationalcognitive, organizational-activity, emotional-volitional, reflexiveevaluative components of the investigated quality, which captures the dynamics and results of knowledge acquisition.

Adult education is a component of continuous education of the individual, which aims at accommodation of the subject in socio-economic and informational changes of society. In Ukraine postgraduate education mainly provides education throughout life, which helps individuals to adapt to the new socio-economic atmosphere. The current list of qualifications of professions and the correspondence of their knowledge to professional competencies can not always satisfy a state or a person, productively carry out social transformations. In Ukraine, since January 2, 2019, the Institute of Career Advisor has been introduced, where specialists will direct clients to skills, knowledge and skills of professionals that are definitely demanded by the community [13].

The questions of the development of adult education identified as the main at international meetings of the "Big Eight" (Cologne Charter, 
Cologne, 1999, Education in the Changing World, Final Document of the "Big Eight" Ministers of Education Meeting, Tokyo, 2000). In 1997, countries of the Commonwealth of Independent States signed an "Agreement on Cooperation in the Spread of Knowledge and Education of Adults" [9]. Accordingly, Article 18 of the Law of Ukraine "On Education" (2017) education of adults is a part of the realization of the right of an adult person to ensure their personal needs and the needs of society and the economy.

An integral part of the system of continuous education is postgraduate education, which provides the needs of citizens in the continuous improvement of the professional level and society in highly skilled professionals. Actuality and demand of this type of education reflects the interest of specialists, specialized institutions and educational institutions in it. The value of the system of postgraduate education is seen in its contribution to the implementation of economic and political tasks and the right of individuals to endogenous development [11, p. 3]. Simultaneous acquisition of educational qualifications and the formation of a person's culture is determined by scientists as vocational education. It is described as a process and the result of acquiring certain knowledge, skills and abilities [16]. According to $\mathrm{M}$. Skuratovskaya, "the modern aspect of mastering professional competences is virtual education, that is, the use of information and communication technologies in teaching" [12, p. 252].

Non-academic education in the general scientific aspect appears as a multi-valued concept. It is considered as a set of practical grounds for professional knowledge, such as the initial conceptual scheme of life-long education, a model of praxis, a large work theory or a group of theories, a way of formulating and solving the problem of lack of skilled workforce. The analysis of the concepts of "nonacademic education" allows us to determine its general characteristics, among which are the generally accepted standards for solving problems of education and society; theoretical, general methodological, praxeological principles of cognition, tools for analyzing various phenomena and processes. In general, it can be emphasized that nonacademic education forms a system in which the most common properties of the professional environment are presented. Non-academic education sets the reference point, the coordinate system in education throughout life, using the universal laws of the evolution of nature, society and man. They make it possible to isolate and establish the connection between the facts, to recognize different mental models, that is, it is better to see reality. The ability to apply this vision in practice gives a great deal of strength, expands the field of opportunity, space for action. The non-academic approach in education is used as a basic concept, which includes interrelated and interdependent elements. Having

The modern paradigm of non-academic education in the context of unlimited professional education 
received the status of a professional category, it allows determining the genesis of many pedagogical phenomena, to identify trends, directions of increase and conceptualization of knowledge in practice, to choose the form of setting the solution of educational problems.

Conclusion. The modern paradigm of non-academic education acts as an activity form of the development of an individual and a specialist, based on the principles of creating a productive rather than reproductive system of transfer and gaining knowledge, taking into account the diversity of subjective and objective challenges of the present. It focuses on the study of the educational process as a system of functions, the incorrect implementation of one of which may affect the education system as a whole. A meaningful characteristic of non-academic education in the broadest sense is an over-complex system, which is in constant development and is regarded as the form of human existence in the world. Based on this understanding, non- academic education is seen as a cumulative method and product of activity. It includes not only education, the formation of professional skills, but also phenomena that go beyond the traditional types and forms of education, such as the joint use of learning and practice, the formation of relationships that will be needed at work, etc. The tasks of non-academic education are obtaining modern knowledge, the development of intelligence, the acquisition of the skills and competences necessary for society, the possibility of personal self-determination, the mastery of the legal norms of interaction of people in society. Today, the education system is an open, self-identifying system that responds to any changes in society's life. Moving from administrative-command to statepublic forms of management and based on a person-oriented paradigm, it allows satisfying the natural and inalienable right of every person to receive education, inclusive of his individual peculiarities, interests and abilities.

\section{REFERENCES}

1. Buiashenko, V. V. (2017). Stalyi rozvytok i suchasna paradyhma osvity. Visnyk Akademiyi pratsi, sotsialnykh vidnosyn i turyzmu, 2, 72-74.

2. Volkovskyi, V. P. (2017). Ideia suspilnosti: politychna filosofiya v Ukraini XX stolittia. NAN Ukrainy, Instytut filosofiyi im. H. S. Skovorody. Kyiv: Akademperiodyka, 264.

3. Voronkova, V. H., Kyvliuk, O. P. (2017). Formuvannia novoi kontseptsiyi innovatsiynoi osvity v umovakh hlobalizatsiyi. Osvitniy dyskurs. Vyd-vo «Hileia», 2, 65-78.

4. Desiatov, T. A. (2002). Suchasne naukove bachennia neperervnoi profesiynoi osvity: stratehiya rozvytku $\mathrm{v}$ masshtabakh heopolitychnykh rehioniv. Neperervna profesiyna osvita: teoriya i praktyka, 2, 9-23.

5. Dolhochub, V., Petrova, N. (2016). Proiavy lokalnosti v pozaakademichni rekonstruktsiyi ukrainskoi tradytsiynoi kultury. Narodna tvorchist ta etnolohiya, 5, 18-22. 
6. Zaitseva, Z. I. (2007). Instytutsionalizatsiya ukrainskoi nauky naprykintsi XIX - na pochatku XX stolittia. Natsionalna akademiya nauk Ukrainy, Instytut istoriyi Ukrainy. Kyiv, 40 .

7. Zakon Ukrainy «Pro osvitu» vid 5.09.2017 No. 2145-VIII. Available at: http://zakon3.rada.gov.ua/laws/show/2145-19/page

8. Kyvliuk, O. (2017). Neformalna osvita v kontseptsii lifelong learning. Osvitniy dyskurs. Vydavnytstvo «Hileia», 1, 22-34.

9. Lukianova, L. B., Nizhyn, P. P., Lysenko, M. M. (2011). Kontseptsiya osvity doroslykh v Ukraini, 24.

10. Orlov, V. F. (2017). Karierni orientatsiyi subiektiv suchasnoi profesiinoi shkoly. Naukovyi visnyk IPTO Profesiyna pedahohika, 13, 15-21.

11. Protasova, N. H. (1999). Teoretyko-metodychni osnovy funktsionuvannia systemy pisliadyplomnoi osvity pedahohiv v Ukraini. Kyiv, 33.

12. Skurativska, M. O., Popadiuk, S. S. (2017). Virtualne osvitnie seredovyshche yak innovatsiyna skladova navchalnoho protsesu u vyshchiy shkoli. Zbirnyk naukovykh prats. Pedahohichni nauky, LXXX (2), 251-255.

13. V Ukraini rozpochynaie robotu instytut kariernoho radnyka. Ukrinform. Available at https://www.ukrinform.ua/rubric-society/2611946-v-ukraini-rozpocinae-robotu-institutkarernogo-radnika.html

14. Donovan, M. S., Bransford, J. D., Pellegrino, J. W. (1999). How people learn: bridging research and practice. National Academy Press, 118.

15. Fox, J. A., Baloy, N., Sens, A. (2014). Mix and Match: Promoting Interdisciplinary Teaching, Learning, and Community through Classroom-level Partnerships. Collected Essays on Learning and Teaching, 7 (2), 142. doi: https://doi.org/10.22329/celt.v7i2.3977

16. Kober, S., (2017). Konzipierung der virtuellen Lehr- und Lernumgebung Düsseldorf : Der Vizepräsident für Alumni-Management und wissenschaftliche Weiterbildung Prof. Dr. Horst Peters (Hg.), 6.

17. Krzych, B. K. (2017). Gdy nauka staje się grą... (De)konstruktywnie i krótko o pewnych (nieczystych) regułach świata akademii. UR Journal of Humanities and Social Sciences, 3 (2), 133-145. doi: https://doi.org/10.15584/johass.2017.2.7

18. Robinson, K. Changing Education Paradigms. Available at: http://www.cfpscourseweb.com/pluginfile.php/1099/block_html/content/RSA\%20\%20Ken\% 20Robinson\%20Lecture\%20-\%20transcript.pdf

КИВЛЮК, О. П. - доктор філософських наук, професор, завідувач кафедри методології науки та міжнародної освіти, Національний педагогічний університет імені М.П. Драгоманова (Київ, Україна)

E-mail: panyolga@ukr.net ORCID: 0000-0002-7900-9299

ЖУКОВА, Г. В. - кандидат педагогічних наук, доцент кафедри методик та технологій дошкільної освіти, Національний педагогічний університет імені М.П. Драгоманова (Київ, Україна)

E-mail: galinazh1299@gmail.com ORCID: 0000-0002-1248-4669

\section{СУЧАСНА ПАРАДИГМА ПОЗААКАДЕМІЧНОЇ ОСВІТИ У КОНТЕКСТІ БЕЗПЕРЕРВНОЇ ПРОФЕСІЙНОЇ ОСВІТИ}

Актуальність дослідження. Розгляд безперервної професійної освіти як соціального інституту обумовлюе актуальність інтеграційного підходу, який передбачає використання комплексу заходів щодо інтеграції та міждисциплінарності сучасного наукового знання, пошуку нових контекстів освіти як продуктивного напрямку розвитку наукових досліджень, де позаакадемічна освіта виступає як The modern paradigm of non-academic education in the context of unlimited professional education 
діяльнісна парадигма, що потребує теоретичного аналізу та наукового обгрунтування. Мета статті - проаналізувати особливості позаакадемічної освіти, як сучасної парадигми, що уможливлює формування креативного фахівця, здатного до професійного і особистісного саморозвитку, задля теоретичного обгрунтування зміни освітнього поля. Аналіз останніх досліджень і публікацій. Концепція безперервної освіти як сучасна освітня парадигма була розглянута в роботах: В. Буяшенко [1], В. Воронкової [3], Т. Десятова [4], О.Кивлюк [8], Л. Лук'янової [9], В. Орлова [10] та інші. Методологія дослідження. В науковому дослідженні використано системний, інформаціологічний, синергетичний методи і підходи, що дають можливість здійснити аналіз сучасної парадигми позаакадемічної освіти. Виклад основного матеріалу. Становлення позаакадемічної освіти розглядається як соціокультурний феномен, який відображає зростаючу потребу особистості в отриманні різноманітних освітніх послуг. Ця освітня система володіє такими ознаками як: організованість, систематичність, професійна спрямованість, безперервність, актуальність по відношенню до вже наявних знань, отриманих особистістю за межами академічної освітньої системи. Основними принципами позаакадемічної освіти, відповідно досліджень вітчизняних та зарубіжних вчених та українських державних програм $\epsilon$ : орієнтація навчання на задоволення актуальних потреб його суб'єктів; зв'язок 3 практикою, який проявляється в спрямованості на здобуття життєвих навичок і підготовку до активної участі в житті суспільства; наявність мобільних гнучких програм, індивідуальних освітніх стратегій, спрямованих на вираження, прийняття i повагу індивідуальних особливостей. Висновки. Сучасна парадигма позаакадемічної освіти виступає як діяльнісна форма розвитку особистості та фахівця, що грунтується на засадах створення продуктивної, а не репродуктивної системи передачі та отримання знань 3 урахуванням всього різноманіття суб'єктивних та об'єктивних викликів сьогодення.

Ключові слова: безперервна освіта, професійна освіта, позаакадемічна освіта, система освіти, інформаційне суспільство.

КИВЛЮК, О.П. - доктор философских наук, профессор, заведующий кафедрой методологии науки та международного образования, Национальный педагогический университет имени М. П. Драгоманова (Киев, Украина)

E-mail: panyolga@ukr.net, ORCID: 0000-0002-7900-9299

ЖУКОВА, Г. В. - кандидат педагогических наук, доцент кафедры методик та технологий дошкольного образования, Национальный педагогический университет имени М.П. Драгоманова (Киев, Украина)

E-mail: galinazh1299@gmail.com, ORCID: 0000-0002-1248-4669

\section{СОВРЕМЕННАЯ ПАРАДИГМА ВНЕАКАДЕМИЧЕСКОГО ОБРАЗОВАНИЯ В КОНТЕКСТЕ НЕПРЕРЫВНОГО ПРОФЕССИОНАЛЬНОГО ОБРАЗОВАНИЯ}

Актуальность исследования. Рассмотрение непрерывного профессионального образования как социального института обусловливает актуальность интеграционного подхода, который предусматривает использование комплекса мероприятий по интеграции и междисциплинарности современного научного знания, поиска новых контекстов образования как продуктивного направления развития научных исследований, где внеакадемическое образование выступает как деятельная парадигма, требует теоретического анализа и научного обоснования. Цель статьи проанализировать особенности внеакадемического образования, как современной парадигмы, что делает формирование креативного специалиста, способного к профессиональному и личностному саморазвитию, для теоретического обоснования изменения образовательного поля. Анализ последних исследований и публикаций. Концепция непрерывного образования как современная образовательная парадигма была рассмотрена в работах В. Буяшенко [1], В. Воронковой [3], Т. Десятова [4], О. 
Кивлюк [8], Л. Лукьяновой [9], В. Орлова [10] и другие. Методология исследования. В научном исследовании использованы системный, информационный, синергетический методы и подходы, позволяющие провести анализ современной парадигмы внеакадемического образования. Изложение основного материала. Становление внеакадемического образования рассматривается как социокультурный феномен, отражающий растущую потребность личности в получении различных образовательных услуг. Эта образовательная система обладает такими признаками как: организованность, систематичность, профессиональная направленность, непрерывность, актуальность по отношению к уже имеющимся знаниям, полученным личностью вне академической образовательной системы. Основными принципами внеакадемического образования, согласно исследований отечественных и зарубежных ученых, украинских государственных программ являются: ориентация обучения на удовлетворение актуальных потребностей его субъектов; связь с практикой, которая проявляется в направленности на получение жизненных навыков и подготовку к активному участию в жизни общества; наличие мобильных гибких программ, индивидуальных образовательных стратегий, направленных на выражение, принятие и уважение индивидуальных особенностей. Выводы. Современная парадигма внеакадемического образования выступает как деятельная форма развития личности и специалиста, основанной на принципах создания производительной, а не репродуктивной системы передачи и получения знаний с учетом всего многообразия субъективных и объективных вызовов современности.

Ключевые слова: непрерывное образование, профессиональное образование, внеакадемическое образование, система образования, информационное общество.

Стаття рекомендована до публікащії д. філос. н., проф. Д. І. Дзвінчук (Івано-Франківськ, Україна) Надійшла до редколегіï: 04.03.2019 р. Прийнята до друку: 14.03.2019 p.

The modern paradigm of non-academic education in the context of unlimited professional education 